\title{
Science Museums: A Panoramic View
}

\author{
Lara Bergers, Utrecht University \\ Didi van Trijp, Leiden University
}

\begin{abstract}
Science museums come in all shapes and sizes. In order to provide an overview of the present-day landscape of science museums, this survey proposes a typology based on their historical origins. It suggests that, despite their distinct beginnings, museums of various types have converged in their institutional identities.
\end{abstract}

As any curator will tell you - and as we have indeed been told by the organizer of this Focus Asection-his or her museum is unique! Although it is easy to dismiss such assertions as a type of misplaced pride (much like that of parents who insist that their own offspring is like no other), there certainly is some truth to such pronouncements. Each institution has its own history, its own guiding principles, and its own one-of-a-kind collection of objects. It is difficult, therefore, to divide the world of museums of science into straightforward categories. Yet in an attempt to provide an overview of the current-day landscape of science museums, that is precisely what this essay will do.

We delve into those science museums in which historical scientific collections of manmade objects (often referred to as artificialia) play a leading role. ${ }^{1}$ As the contributions to this Focus section only tangentially touch on natural historical, technological, and medical museums, ${ }^{2}$ these institutions fall beyond the scope of this survey. Science centers, which typically do not rely on historical artifacts, are also not included. We identify three types of science museum on the basis of the intentions with which they were established. Of course, these types are merely approximations, and sensitivity to the unique characteristics of each institution must not be lost.

First, there are those collections that have become "fossilized," surviving virtually unchanged in their original form and setting. They were not initially intended to assemble

\footnotetext{
Lara Bergers is completing her master's degree in history and philosophy of science at Utrecht University. In her current project she looks at the history of lie detection in the Netherlands. She previously worked as an editorial assistant at Isis. l.bergers@uu.nl. Didi van Trijp is a Ph.D. candidate at Leiden University Centre for the Arts in Society, where she researches natural historical inquiries into the underwater world in eighteenth-century Europe as part of a NWO-funded project. Faculty of Humanities, P.N. van Eyckhof 3, 2311 BV Leiden, Netherlands; d.r.van.trijp@hum.leidenuniv.nl.

Acknowledgments. We are grateful to Ad Maas and H. Floris Cohen for granting us the opportunity to contribute to this Focus section and greatly appreciate the guidance provided to us by the former. We would also like to thank the other contributors to this Focus section, as well as the anonymous referee, whose comments have been most helpful in developing and refining this piece.

${ }^{1}$ Some authors make a distinction between the terms "history of science museum" and "science museum," but the reasons for doing so vary greatly. We here treat the terms as equivalent. Victoria Cain uses these terms in a different manner, for reasons made clear in her contribution to this Focus section.

${ }^{2}$ An exception is the contribution to this Focus section by Marta Lourenço and José Dias, which does encompass collections of naturalia.
}

Isis, volume 108, number 2. (C) 2017 by The History of Science Society. All rights reserved. 0021-1753/2017/0108-0010\$10.00.

366 
objects specifically for their historical significance, nor - in most cases - did they initially offer entrance to a broader public beyond noble or learned circles. When visitors today wander into the Mathematisch-Physikalischer Salon in Dresden, which dates back to 1720, they are met by an impressive collection of optical and mathematical instruments. Many of these objects stem from the Kunstkammer created by the Elector of Saxony around 1560 and served as instruments for surveying and measuring the princely territories, while some were handled in the context of intellectual and social play in courtly setting. The collection of the AstronomischPhysikalisches Kabinett in Kassel, founded around 1700 by the landgrave Karl of Hesse-Kassel, can likewise be admired today in its largely unchanged setting. "Fossilized" early modern collections, however, are relatively rare. Many of these cabinets were, sadly, lost-although this might not mean that they are lost forever: in their contribution to this Focus section Marta Lourenço and José Dias describe a fascinating case of a "found" collection ${ }^{4}$ - while others were absorbed into larger museums. The scientific instruments collection of the Medici, for example, is now part of the Galileo Museum. ${ }^{5}$

Other surviving "fossilized" collections were assembled from the eighteenth century onward by learned societies (both civic and with royal commendation) that sought the most recent, sophisticated, or effective instruments with which nature could be investigated and demonstrated to their respective publics (society members, scholars, students, the bourgeoisie). ${ }^{6}$ As time went by, however, older objects were not shed from the collections. In this way, collections became historic as a matter of course. Collections of instruments such as that of Teylers Museum in Haarlem (1779) and the Royal Institution in London (1799) have remained in their original settings. ${ }^{7}$ As has been cogently argued in the case of Teylers Museum, these institutions may be said to represent the history of their own science, rather than the history of science as a whole. Related to this type are observatories that now serve as museums. The Museum of Astronomy and Related Sciences in Rio de Janeiro, for instance, is housed in an observatory that was conceived under Portuguese imperial rule in 1825. Another such example is the Pulkovo Observatory, built on Tsar Nicholas I's estate near Saint Petersburg in 1839.

\footnotetext{
${ }^{3}$ On the Dresden museum see Michael Korey, The Geometry of Power, the Power of Geometry: Mathematical Instruments and Princely Mechanical Devices from around 1600 in the Mathematisch-Physikalischer Salon (Munich: Deutscher Kunstverlag, 2007), pp. 17-25; and Sven Dupré and Korey, "Optical Objects in the Dresden Kunstkammer," in European Collections of

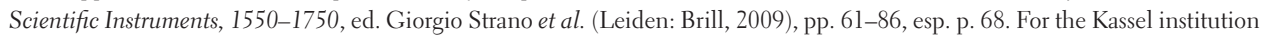
see Karsten Gaulke, "Ein 'House of Solomon' für Kassel: Landgraf Karl und die Gründung des Kunsthauses," in Optica: Optische Instrumente am Hof der Landgrafen von Hessen-Kassel, ed. Gisela Bungarten (Petersberg: Imhof, 2011), pp. 9-24, esp. p. 10. ${ }^{4}$ See also Marta C. Lourenço, "Royal Cabinets of Physics in Portugal and Brazil: An Exploratory Study," Opuscula Musealia, 2011, 19:71-88.

${ }^{5}$ Filippo Camerota, "The 'Mathematics Rooms,"” in Displaying Scientific Instruments: From the Medici Wardrobe to the Museo Galileo, ed. Camerota (Milan: Goppion, 2012), pp. 3-8.

${ }^{6}$ Anthony J. Turner, "Paris, Amsterdam, London: The Collecting, Trade, and Display of Early Scientific Instruments, 18301930," in Scientific Instruments: Originals and Imitations: The Mensing Connection, ed. Peter de Clercq (Leiden: Museum Boerhaave, 2002), pp. 23-47, on p. 23; quoted in Paolo Brenni, "The Birth of Museums of the History of Science," in Displaying Scientific Instruments, ed. Camerota, pp. 57-74, on p. 57.

${ }^{7}$ Teylers Museum also held a selection of fine art, and developments in the display of this art collection in the nineteenth century had a bearing on the status of the instrument collection. See Martin Weiss, “'Monuments of Science': How the Teyler Museum's Instrument Collection Became Historical," in Cabinets of Experimental Philosophv in Eighteenth-Century Europe, ed. Jim Bennett and Sofia Talas (Leiden: Brill, 2013), pp. 195-214, esp. pp. 201-203. The collection of the Royal Institution can be found in its Faraday Museum. See Irena M. McCabe and Frank A. J. L. James, "Collections X: History of Science and Technology Resources at the Royal Institution of Great Britain," British Journal for the History of Science, 1984, 17:205-209, esp. p. 208.

${ }^{8}$ Weiss, “'Monuments of Science,"” p. 214 (Teylers Museum); Philip C. Keenan, "The Earliest National Observatories in Latin America," Lournal for the Historv of Astronomv, 1991, 22:21-30, esp. pp. 24-25; and Simon Werrett, "The Astronomical Capital of the World: Pulkovo Observatory in the Russia of Tsar Nicolas I," in The Heavens on Earth: Observatories and Astronomy in
} 
The relatively closed character of the abovementioned collections forms an interesting contrast with an institute founded in Paris in 1794-namely, the Conservatoire National des Arts et Métiers. This conservatory, featuring state-of-the-art instruments and machines, is often singled out as the very first example of an institute of our second type, founded with the express aim of propagating public understanding (and admiration) of science. ${ }^{9}$ Other such museums followed around the turn of the twentieth century. The Deutsches Museum in Munich was founded in 1903 by Oskar von Miller, who was familiar with both the Conservatoire National des Arts et Métiers and the South Kensington Museum. ${ }^{10}$ The Science Museum in London, initially part of the South Kensington Museum (1857), was separated from the arts collection of that museum in 1909.1 ${ }^{11}$ These museums allied themselves less with individuals and institutes; instead they emphasized the importance of science and technology for the nation, while never losing sight of science's international context. ${ }^{12}$

The Deutsches Museum pioneered new ways of engaging the public: "fully functional exhibits, experiments and demonstrations in which the visitor could take part, as well as complete mock ups, replicas and dioramas," became integral to the museum experience. The Science Museum adopted and adapted this new approach for the London public. An interesting development unfolded when, by the time the Adler Planetarium in Chicago opened in 1930, its scope had been expanded to encompass an Astronomical Museum too, including both "ancient" and modern objects to inform a broad public of "the successive advances of science ... in such ways as to win general understanding." The institute's absorption of a collection of historical instruments gave its spectacular planetary projection shows the coveted scholarly aura. ${ }^{13}$

The Smithsonian Institution came into the possession of a large number of cutting-edge instruments and technologies after the 1876 Centennial Exhibition in Philadelphia, when many exhibiting nations, plagued by economic hardships, decided to leave their exhibits behind. It would take until 1964 for a dedicated science museum to spin off from the Smithsonian's National Museum, which, not unlike the South Kensington Museum, was a catch-all facility. In 1976 a second dedicated science museum arose in the form of the National Air and Space Museum. Despite the international origins of the Smithsonian collection, both museums emphasized American prowess in science and technology. This is hardly surprising given their Cold War context. ${ }^{14}$

Nineteenth-Century Science and Culture, ed. David Aubin, Charlotte Bigg, and H. Otto Sibum (Durham, N.C.: Duke Univ. Press, 2010), pp. 33-57, esp. p. 36.

${ }^{9}$ The conservatory was meant to instill understanding of the importance of innovation in a wide public, "technicienne ou non": Bruno Jacomy, "Du Cabinet au Conservatoire: Les instruments scientifiques du Conservatoire des Arts et Métiers á Paris," Journal for the History of Collections, 1995, 7:227-233, on p. 227.

10 "If only it were possible that Germany, too, would have a major museum dedicated to science and technology-a place of knowledge, and one that would encourage learning," he lamented in 1891. Quoted in Wolf Peter Fehlhammer and Walter Rathjen, "The Deutsches Museum: Past, Present, and Future," Arbor, 1999, 164:403-433, on p. 403.

${ }^{11}$ Richard Dunn, "More Artistic than Scientific: Exhibiting Instruments as Decorative Art in the Victoria and Albert Museum," in Scientific Instruments on Display, ed. Silke Ackermann, Richard Kremer, and Mara Miniati (Leiden: Brill, 2014), pp. 61-76.

${ }^{12}$ Otto Mayr, "Historical Survey," in The Deutsches Museum: German Museum of Masterworks of Science and Technology, Munich, trans. Timothy Slater (London: Scala, 1990), pp. 7-24, esp. p. 9; Tom Scheinfeldt, "The International Context and the Context of Internationalism," in Science for the Nation: Perspectives on the History of the Science Museum, ed. Peter J. T. Morris (London: Palgrave Macmillan, 2013), pp. 294-311; and Wilhelm Füßl, Oskar von Miller, 1855-1934: Eine Biografie (Munich: Beck, 2005).

${ }^{13}$ Fehlhammer and Rathjen, "Deutsches Museum" (cit. n. 10), p. 403; Philip Fox, Adler Planetarium and Astronomical Museum: An Account of the Optical Planetarium and a Brief Guide to the Museum (Chicago: Donnelly, Lakeside, 1933), p. 5; and Liba Taub, “'Canned Astronomy' versus Cultural Credibility: The Acquisition of the Mensing Collection by the Adler Planetarium," J. Hist. Collect., 1995, 7:243-250

${ }^{14}$ Scheinfeldt, "International Context and the Context of Internationalism" (cit. n. 12), pp. 301-307. 
Whereas the institutions in this second group aspired to educate and improve the public and attracted a broad range of visitors with their lively displays, a third type of museum arose in the twentieth century in dialogue with anxieties about preservation. ${ }^{15}$ Groups of scientists in various countries fretted over languishing instrument collections and rallied for museums in which their (often national) scientific heritage could be preserved. The Boerhaave Museum in Leiden and the Museo Nazionale di Storia della Scienza in Florence (now the Galileo Museum) are clear examples. The latter institute was closely aligned with the University of Florence and had contribution to scholarly research in the history of science as its primary aim. ${ }^{16}$

The Oxford History of Science Museum similarly had a close connection to its university. Robert T. Gunther, a zoologist and lecturer at Oxford, was passionate about preserving the material scientific heritage of his university and lobbied hard to establish a museum for the objects that he found on its premises. It was only when the paper manufacturer Lewis Evans offered his impressive instrument collection to the university that Gunther's dream was realized. Gunther repeated this feat at Cambridge, which led to the establishment of the Whipple Museum. Both museums were "an important part of the generative context for teaching and research . . a at both universities." 17 The Harvard Collection of Historical Scientific Instruments similarly benefited greatly from the generosity of a zealous collector: David P. Wheatland's personal collection of scientific instruments was started with the express aim of supplementing the university's holdings.

Before starting his personal collection, Wheatland, who worked in Harvard's physics department, had already been hard at work to find and preserve instruments that had been purchased by the university for the purposes of research and teaching over a period of some 250 years. Similarly, the physical instruments at the University of Uppsala's Museum Gustavianum and the microscopes displayed at the Macleay Museum (part of the University of Sydney) were used in teaching. ${ }^{18}$ University collections may include stellar objects that have significance beyond their own locale: the Koryŏ University Museum in Seoul holds the armillary clock made by Song Iyŏng in 1669. ${ }^{19}$ The enthusiasm with which universities have been assembling collections from the late sixteenth century onward is still seen today in the various efforts to expand existing university museums or set up new ones. ${ }^{20}$

We have distinguished between different types of museums on the basis of their historical origins. It is safe to say that the circumstances of their inception have contributed to their

\footnotetext{
${ }^{15} \mathrm{Jim}$ Bennett, "European Science Museums and the Museum Boerhaave," in 75 jaar Museum Boerhaave (Leiden: Museum Boerhave, 2006), pp. 73-78, esp. p. 77. See also the introduction to this Focus section by Ad Maas.

${ }^{16}$ Marco Beretta, "Andrea Corsini and the Creation of the Museum of the History of Science in Florence (1930-1961)," in Scientific Instruments on Display, ed. Ackermann et al. (cit. n. 11), pp. 1-36, esp. p. 6.

${ }^{17}$ J. A. Bennett, "Museums and the Establishment of the History of Science at Oxford and Cambridge," Brit. J. Hist. Sci., 1997, 30:29-46, on p. 30.

${ }^{18}$ William J. H. Andrewes, “The Legacy of David Wheatland," Nuncius, 2001, 16:687-701, esp. p. 688; John Worley and Urban Josefsson, "Managing the Scientific Heritage of a Medieval University: The Case of Uppsala University," Opusc. Museal., 2010, 18:51-60; and Julian Holland, Microscopes and Microscopy: Instruments and Related Items in the Macleay Museum (Sydney: Macleay Museum, 1989), p. 7.

${ }^{19}$ This object combines Chinese, Arabic, and European traditions of astronomical clock making. See Sang-woon Jeon, Science and Technology in Korea: Traditional Instruments and Techniques (Cambridge, Mass.: MIT Press, 1974), p. 71.

${ }^{20}$ The concerted expansion effort of Japan's university museums has been described in Tatsufumi Kinoshita and Ryo Yasui, "University Museums in Japan: A Time of Transition," Museum International, 2000, 52(3):27-31; efforts in Toronto have been covered in Erich Weidehammer, "Museums and Scientific Material Culture at the University of Toronto," Studies in History and Philosophv of Science, 2013, 44:725-734. For earlier efforts see William Schupbach, "Some Cabinets of Curiosities in European Academic Institutions," in The Origins of Museums: The Cabinet of Curiosities in Sixteenth-and Seventeenth-Century Europe, ed. Oliver Impey and Arthur MacGregor (Oxford: Clarendon, 1985), pp. 169-178, esp. pp. 169-172.
} 
present-day character. However, it is also pertinent to note that the shape of these institutions has been continuously influenced by social, economic, political, and scientific factors. The early private collections, stemming from a time when our category of "science" had not yet been created and our notion of a museum had not taken root, have now become accessible to a broader public and have grown into museums in our modern sense. ${ }^{21}$

Likewise, those museums founded to edify the broader public through exposure to the wonders of science have seen shifts in their intended audiences: the Science Museum, for example, initially expected to welcome mainly experts and teachers but was surprised in the 1920s by large groups of young visitors. The museum responded to this development in 1931 by opening a Children's Gallery, which relied on a more hands-on approach pioneered by the Deutsches Museum. Since that time, the Science Museum has continuously tried to strike and maintain a balance between catering to different groups of visitors. ${ }^{22}$

The museums that sprang from the desire to preserve scientific instruments of historical significance are today no less engaged in promoting a greater understanding of scientific cultural heritage than those museums that were originally conceived for instruction to a wide public. Despite their distinct beginnings, museums now often grapple with very similar challenges. What connects contemporary science museums in the end is an ongoing pursuit of the best ways to preserve historical scientific objects and to present the history of science to a wide array of audiences in a museum setting - and it is from this shared sense of identity that this Focus section proceeds.

\footnotetext{
${ }^{21}$ That this is not a necessary development is described by Victoria Cain in her contribution to this Focus section.

${ }^{22}$ Scheinfeldt, "International Context and the Context of Internationalism" (cit. n. 12), pp. 300-301. On the importance of finding a balance among the needs of various groups see Peter J. T. Morris, "Introduction," in $\underline{\text { Science for the Nation, ed. Morris }}$ (cit. n. 12), pp. 1-10, esp. p. 4.
} 